\title{
Persepsi Dosen PAI di Perguruan Tinggi Umum tentang Praktek Perbankan Syariah dan Konvensional
}

\author{
Izzatul Mardhiah \\ Universitas Negeri Jakarta \\ izzatul-mardhiah@unj.ac.id \\ Rihlah Nur Aulia \\ Universitas Negeri Jakarta \\ Rihlah-nuraulia@unj.ac.id \\ Sari Narulita \\ Universitas Negeri Jakarta \\ Sari-narulita@unj.ac.id
}

\begin{abstract}
The study describes the perception of Islamic Religious Lecturers (PAI ) at Public University (PTU) about the practice of Islamic and conventional banking. This study is a descriptive qualitative research. The data were collected through a questionnaire distributed among several PAI Lecturers in Jakarta and other regions. This research used the Improvisation theory formulated by Ibrahim Warde, which stated about traditionalist, modern and moderate view about bank interest. The study concluded that PAI lecturers perceptions in PTU are divided into three views. Most respondents tended to have the modern perspective, accepting the concept of debt interest as a banking transaction instrument, and regarded it as a halal transaction. The second group is classified as the traditionalist, they consider the bank interest is additional loans, falling under the usury and is unlawful. The last group is between traditionalist and modern and stated that the bank interest is syubhat. PAI lecturers also have different views on Islamic banking. The majority of respondents considered that Islamic banking is not much different from conventional, only a few respondents stated that there are many differences between conventional and Islamic banks.
\end{abstract}

Keywords:Perception, Islamic banking, PAI lecture,Bank interest

\begin{abstract}
Abstrak
Penelitian mendeskripsikan persepsi Dosen Pendidikan Agama Islam (PAI) di Perguruan Tinggi Umum (PTU) tentang praktek perbankan syariah dan konvensional. Kajian ini merupakan penelitian kualitatif deskriptif. Data dikumpulkan melalui angket yang disebarkan kepada beberapa Dosen PAI di Perguruan Tinggi Jakarta dan luar Jakarta. Teori persepsi merupakan improvisasi dari teori yang dirumuskan Ibrahim Warde tentang bunga bank, yakni pandangan aliran tradisionalis, modern dan moderat. Penelitian menyimpulkan bahwa Dosen PAI di PTU terbagi kepada tiga pandangan. Sebagian besar responden dikelompokkan kepada golongan modern, menerima konsep bunga sebagai instrumen transaksi di perbankan, dan menganggapnya sebagai transaksi yang halal. Kelompok kedua digolongkan tradisionalis, mereka menganggap bunga bank adalah tambahan pinjaman, termasuk riba dan hukumnya haram. Terakhir adalah kelompok yang berada di antara tradisionalis dan modern. Kelompok ketiga menyatakan bahwa
\end{abstract}


hukum bunga bank adalah syubhat. Dosen PAI juga mempunyai pandangan yang berbeda mengenai perbankan syariah. Mayoritas responden menilai perbankan syariah tidak jauh berbeda dengan perbankan konvensional, beberapa responden menyatakan bahwa terdapat banyak perbedaan antara bank konvensional dan bank syariah.

Kata Kunci: Persepsi, Dosen PAI PTU, Bank konvensional, Bank syariah

\section{A. Pendahuluan}

Tren pemanfaatan produk bank syariah terus mengalami perkembangan, namun pertumbuhan industri keuangan syariah tidak seperti yang diharapkan. Angka pertumbuhan industri keuangan syariah nasional masih berada di bawah 5\%. Meski sudah berjalan hampir 16 tahun sejak Bank Syariah pertama kali didirikan di tanah air. Pertumbuhan yang selalu hanya pada angka 5\% menjadi semacam momok bagi industri ini. Pertumbuhan lembaga keuangan syariah sempat menembus angka di atas 5\% lebih sedikit dua tahun lalu, yaitu ketika Bank BPD Aceh dikonversi menjadi bank syariah. Namun, kembali menurun pada periode 2016-2017. ${ }^{1}$

Terdapat beberapa hal yang disinyalir menjadi kendala perkembangan sistem ekonomi syariah di Indonesia, selain keterbatasan sumber daya dan regulasi, dukungan dari masyarakat muslim terhadap sistem syariah juga masih minim. Dengan jumlah populasi penduduk muslim yang sangat besar, sejatinya share dan pertumbuhan bank syariah di Indonesia cukup tinggi. Namun kenyataannya, potensi yang besar tersebut tidak dengan sendirinya dapat memicu pertumbuhan bank syariah menjadi semakin cepat. Selama ini, bagi sebagian umat muslim, posisi bank syariah masih sebagai alternatif di samping keberadaan bank konvensional. Bahkan di kalangan sarjana muslim pun masih terjadi perdebatan sengit mengenai masalah legalitas dan penerimaan terhadap praktek keuangan yang berjalan di perbankan syariah. Kalangan akademisi muslim pada mulanya menjadi harapan untuk mensosialisasikan bank syariah bagi masyarakat banyak, bahkan peran mereka menjadi tulang punggung dalam meyakinkan masyarakat perguruan tinggi tentang keunggulan bank syariah.

Terlepas dari kekurangan dan kelemahan yang dimiliki perbankan syariah di Indonesia saat ini, perlu kiranya untuk memotret bagaimana posisi akademisi muslim khususnya para pengajar/dosen Pendidikan Agama Islam (PAI) tentang praktek perbankan syariah dan konvensional saat ini. Persepsi mereka terhadap perbankan syariah juga akan

\footnotetext{
${ }^{1}$ https://ekbis.sindonews.com/read/1178444/178/industri-keuangan-syariah-jalan-di-tempat1486632486
} 
menjadi pertimbangan dan acuan dalam memetakan segmen pasar industri keuangan syariah, sebab mereka memeliki posisi strategis untuk mempengaruhi dan meyakinkan para mahasiswa dan masyarakat di lingkungan PTU tentang keunggulan bank syariah sehingga membantu percepatan pengembangan bank syariah di Indonesia.

Selama ini, keterlibatan Sarjana Muslim ikut andil menumbuh kembangan perbankan syariah di Indonesia dari sisi pemikiran masih lebih banyak didominasi Sarjana Ekonomi Syariah, bahkan, tidak jarang terjadi perbedaan pandangan antara Sarjana Ekonomi Syariah dengan Sarjana Agama Islam lainnya mengenai praktek perbankan syariah saat ini, baik mengenai aspek hukum fiqh maupun praktek perbankan syariah secara keseluruhan, termasuk juga perdebatan tentang sistem perbankan konvensional itu sendiri. Untuk itu, penelitian ini bertujuan untuk memetakan kembali persepsi dan posisi sarjana agama Islam, khususnya pengajar Pendidikan Agama Islam di PTU tentang praktek perbankan konvensional dan sistem syariah.

Diskursus hukum bunga bank termasuk isu yang cukup jenuh dan berulang-ulang dalam kajian fikih apalagi dalam perbincangan kajian keuangan syariah, namun tren diskusi cenderung semakin dinamis dan lebih kompleks. Hal ini dikaitkan dengan keberadaan bank syariah yang berdampingan dengan bank-bank konvensional. Bagi sebagian kalangan mungkin perdebatan telah usai dan menemukan jalan keluar akan keraguan status bunga bank, namun tidak sedikit pula yang justru mengukuhkan status kehalalan bunga bank justru pada saat bank-bank yang beroperasional dengan sistem syariah semakin menjamur di mana-mana.

Menyoroti tentang hukum bunga bank, para ulama sejak dulu hingga kini menyikapinya secara berbeda, seiring dengan terjadinya sejumlah revisi fatwa terkait dan pergeseran pandangan setelah keberadaan bank syariah sebagai pengganti bank dengan sistem bunga.

Sebelum bank syariah hadir, ada beberapa pandangan tentang hukum bunga bank. Satu pandangan menyatakan kehalalalannya, ${ }^{2}$ yang kedua menyatakannya haram, ${ }^{3}$ dan lainnya memandangnya sebagai hal yang mutashabihat dengan beberapa persyaratan, dan terakhir hanya membolehkan pada pinjaman produktif. ${ }^{4}$ Dalih kelompok pertama berlandas pada penafsiran bahwa bunga bank tidak termasuk haram, dianggap tidak sama dengan

\footnotetext{
2 Abdurrahman Ghazaly, dkk, Fiqh Muamalat, (Jakarta, Kencana Prenada Media Group, 2010), h. 224.

${ }^{3}$ Abdurrahman, Fiqh Muamalat, h. 224.

${ }^{4}$ Abdurrahman, Fiqh Muamalat, h. 225.
} 
riba karena tidak mencukupi syarat, seperti tingkat bunga yang tidak berlipat ganda, dilakukan oleh sebuah lembaga bukan individu secara personal, serta bersifat produktif dan mendukung pertumbuhan ekonomi, sampai kepada alasan dan pandangan yang menyebutkan bahwa tidak semua bunga dianggap riba jika tingkat bunga rendah (toward tolerable rate $)^{5}$ sehingga tidak dapat disebut mengandung unsur eksploitasi (al-zulm).

Kelompok kedua meletakkannya pada syarat- syarat tertentu, yakni apakah pinjaman tersebut bersifat produktif atau konsumtif, atau kah kredit yang dikenakan bunga tersebut berasal dari bank swasta atau bank negara. Bagi bunga yang dikenakan pada kredit konsumtif atau kredit yang dikeluarkan oleh bank swasta hukumnya haram, dan kredit produktif atau kredit yang dikeluarkan bank pemerintah hukumnya mutashabihat. ${ }^{6}$ Pandangan yang ketiga menyatakan bahwa hukum bunga bank adalah haram apapun bentuk dan sifatnya. Karena setiap tambahan dalam utang piutang termasuk pada jenis riba yang dilarang dalam Alquran dan hadis, tanpa melihat pada jumlah, bentuk pinjaman, atau pun pada siapa pelakunya.

Di samping beberapa pandangan tadi, dinamika pemikiran mengenai polemik hukum bunga bank semakin marak dibicarakan sejak kemunculan ilmu ekonomi syariah yang berujung pada berdirinya bank syariah dan lembaga keuangan syariah lainnya di sejumlah negara.

Menarik apa yang dilontarkan oleh Ibrahim Warde yang menggunakan pendekatan dikotomis 'tradisional' versus 'modern,' sebagai cara menganalisis fenomena ini. 7 Tradisionalisme' sebagai pendekatan yang biasa pemahaman tekstual-literailitik terhadap sehingga umumnya cenderung legalistik, sedang pendekatan lainnya menggunakan pemahaman kontekstual yang berlandaskan semangat keagamaan serta menerima inovasiinovasi non-Islam melalui pemahaman yang berbasis moral universal. ${ }^{8}$

Berdasarkan dikotomi yang dirumuskan Warde tersebut, maka pendekatan formal selalu dihubungkan dengan paradigma tradisionalisme, diidentikkan dengan pemahaman teks-teks agama secara tekstual, hingga menciptkan fikih yang bernuansa legal-

\footnotetext{
${ }^{5}$ Sri-Edi Swasono," Ekonomi Islam dalam Pancasila, Paper International Seminar on Implemetation of Islamic Economics, Surabaya, 1-3 Agustus 2008, h. 7

${ }^{6}$ Abdurrahman Ghazaly, dkk, Fiqh Muamalat, (Jakarta, Kencana Prenada Media Group, 2010), h. 225. Lihat juga Husni Thoyar, " Bunga Bank dan Riba dalam Perspektif Islam,” Jurnal Equibrilium, Ekonomi dan Kemasyarakatan, Vol 2, No 2 Mei-Agustus 2004, h. 54-55.

${ }^{7}$ Ibrahim Warde, Islamic Finance in The Global Economy . (Edinburgh: Edinburgh University Press, (2000), h. 88.

${ }^{8}$ Ibrahim Warde, Islamic Finance in The Global Economy . (Edinburgh: Edinburgh University Press, (2000), h. 88. Buchori, M. N. (2012, November). Kajian Fiqh, antara Pendekatan Substansial dan Pendekatan Formal . Diambil kembali dari http://mazinov.wordpress.com/2012/11/01/antara-pendekatansubstansial- dan-pendekatan-formal-dalam-kajian-fiqh/.
} 
formalistik. Sedangkan, pendekatan substansial dianggap mewakili pemahaman yang menekankan pada terpenuhinya prinsip moral dan tujuan hukum, namun lebih longgar dalam merumuskan aturan-aturan yang bersifat prosedural dan legal-formalistik. ${ }^{9}$ Jika dibuat model lain yang berada di antara keduanya, maka akan ditemukan satu cara pandang lagi yakni yang berada di antara kedua.

Berdasarkan cara pandang tersebut, setelah bank syariah hadir di tengah masyarakat dunia, terjadi semacam pergeseran status hukum bunga bank di kalangan cendikiawan muslim. Bagi beberapa kalangan yang sebelumnya meletakkan posisi shubhat terhadap bunga bank selanjutnya direvisi dan status hukum shubhat dicabut, dan menetapkannya sebagai salah satu bentuk transaksi yang haram. Penegasan status keharaman bunga bank secara formal dtegaskan melalui fatwa MUI pada tahun 2003, ${ }^{10}$ selang tiga tahun berikutnya diikuti oleh Organisasi Muhammadiyyah yakni tahun 2006. ${ }^{11}$ Bahkan bukan hanya terkait dengan status bunga bank, sebagian kalangan juga mempersoalkan status bagi hasil atau produk-produk keuangan yang dikeluarkan bank syariah, yang dianggap mempunyai kemiripan dengan bunga bank konvensional.

Seiring dengan perjalanan bank syariah yang beroperasi secara berdampingan dengan bank konvensional, kemudian diikuti oleh sejumlah fatwa yang dikeluarkan oleh lembaga keagamaan otoritatif yang tampak mendukung pertumbuhan bank syariah, tidak serta merta mengubah cara pandang sebagian umat muslim terhadap status hukum bunga bank. Hal ini dimungkinkan oleh sejumlah faktor seperti kondisi sosial ekonomi dan juga cara pandang keagamaan mengenai transaksi kredit dengan sistem bunga yang dianggap sebagai kebutuhan masyarakat modern yang tidak sepenuhnya dapat tergantikan oleh sistem bank syariah.

Diakui bahwa sejumlah persoalan dan kelemahan yang dimiliki oleh bank syariah tidak sepenuhnya memenuhi kebutuhan konsumen yang masih terikat dan loyal dengan bank konvensional, di samping itu, para akademisi muslim tampaknya juga tidak terlalu masif memberikan dukungan dan mensosialisasikan sistem berbasis syariah ini kepada masyarakat muslim terutama di lingkungan akademik. Sehingga pada akhirnya menjamurlah persepsi yang menyamakan sistem syariah dengan sistem konvensional atau paling tidak menganggapnya hanya berbeda sedikit saja dari pendahulunya, dan termasuk

${ }^{9}$ Ibrahim Warde, Islamic Finance in The Global Economy . (Edinburgh: Edinburgh University Press, (2000), h. 88 . Baca juga Izzatul Mardhiah dalam , Prinsip Keadilan Dalam Penetapan Biaya Ijarah di Pegadaian Syariah, (Semarang, Pangudi Ilmu, 2013), h. 4

${ }^{10} \mathrm{https}: / /$ www.hisbah.net/fatwa-mui-tentang-bunga-bank/

${ }^{11}$ http://tarjih.muhammadiyah.or.id/muhfile/tarjih/download/Fatwa\%2008-2006_Bunga\%20Bank.pdf 
yang bersikap demikian adalah akademisi-akademisi di bidang Pendidikan Agama Islam pada sejumlah Perguruan Tinggi Umum.

\section{B. Metodologi Penelitian}

Penelitian ini merupakan penelitian survey (survey research), dengan menggunakan pendekatan deskriptif kualitatif, yaitu penelitian yang berupaya menghimpun data, mengelola dan menganalisis serta menafsirkan secara kualitatif. Penelitian ini menggunakan pendekatan keuangan syariah. Adapun metode analisis yang digunakan adalah metode normatif-komparatif, yakni membandingkan komponenkomponen data dengan indikator-indikator tertentu. Jenis data yang digunakan pada penelitian ini terdiri dari dua, yaitu data primer dan data sekunder. Data primer terdiri dari data hasil survey lapangan yang dikumpulkan melalui penyebaran angket. Adapun data sekunder berupa buku-buku, hasil penelitian, artikel jurnal, dan artikel-artikel yang diupload melalui internet.

Adapun populasi penelitian ini adalah Dosen PAI di Perguruan Tinggi Umum. Sampel diambil secara acak (random sampling) di beberapa perguruan tinggi di Jakarta dan di luar Jakarta, beberapa dari anggota perhimpunan Dosen PAI seluruh Indonesia (ADPISI), dan beberapa yang tidak bergabung dengan asosiasi tersebut. Adapun tekhnik analisis data dalam penelitian ini menggunakan tehnik content analysis (analisis isi) dengan menggunakan tehnik perbandingan secara induktif. Tempat penelitian dilakukan di Universitas Negeri Jakarta, dengan mengambil responden dari berbagai perguruan tinggi umum.

\section{Hasil dan Pembahasan}

\section{1) Deskripsi Responden}

Responden penelitian ini adalah dosen PAI dari berbagai Perguruan Tinggi Umum di Jakarta dan di luar Jakarta, baik swasta maupun negeri, yang bersedia menjawab angket online yang disebarkan melalui internet dan media sosial. Responden terdiri dari 19 orang pria, dan 6 orang wanita, sehingga keseluruhan responden penelitian berjumlah 25 orang. Dosen PAI yang menjadi responden penelitian ini mengenyam pendidikan dari berbagai lintas keilmuan. Umumnya mereka berpendidikan Kajian Islam dan PAI, hanya dua rensponden yang pernah bependidikan di Bidang Ekonomi Islam. Dilihat dari tingkat strata pendidikan, dari 25 repsonden, 14 berpendidikan S3 dan sisanya berpendidikan S2. 


\section{2) Perbedaan Persepsi Dosen PAI di PTU tentang Bank Syariah dan Bank}

\section{Konvensional}

\section{a. Persepsi Dosen PAI di PTU tentang Hukum Bunga Bank}

Sebagaimana yang dipaparkan sebelumnya, penelitian ini bertujuan untuk mengungkapkan bagaimana pandangan Dosen dan Pengajar Pendidikan Agama Islam di Perguruan Tinggi Umum tentang perbankan syariah. Namun untuk menganalisisnya secara komprehensif, diperlukan pula pengetahuan dan pandangan mereka tentang hukum bunga bank konvensional, karena berdasarkan pengamatan sementara seperti yang disinggung sebelumnya, sikap dan cara pandangan terhadap bunga bank tidak serta merta berubah setelah keberadaan bank syariah, dan ini juga terjadi di kalangan pengajar PAI di sejumlah Perguruan Tinggi Umum. Tentang bagaimana pandangan responden mengenai hukum bunga bank didapatkan hasil sebagai berikut:

\section{Diagram I. Persepsi Dosen PAI tentang Hukum Bunga Bank}

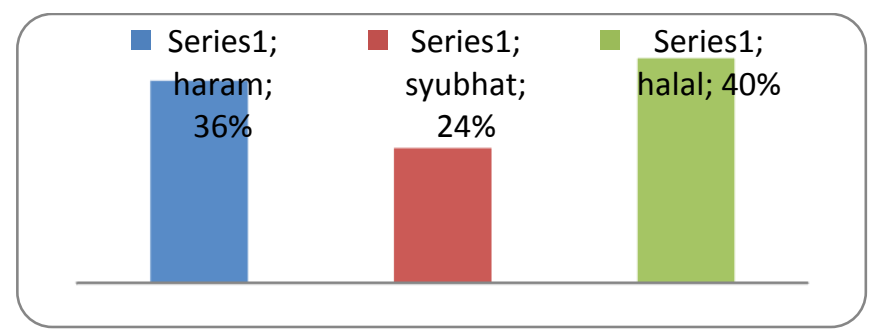

Berdasarkan asumsi awal yang dikemukakan dalam latar belakang penelitian ini, terlihat bagaimana fenomena status hukum bunga bank konvensional di kalangan dosen PAI di PTU. Dalam diagram di atas menunjukkan bagaimana pandangan dari 25 Dosen PAI yang merupakan responden penelitian ini. Terdapat $40 \%$ orang dari 25 Dosen PAI di PTU yang menyatakan bahwa bunga bank hukumnya halal, jumlah tersebut adalah mayoritas dan lebih banyak dari Dosen PAI yang menyatakan hukumnya haram atau pun syubhat. Kesimpulan ini cukup mengejutkan jika dikaitkan dengan adanya fatwa-fatwa tentang hukum bunga bank, terutama setelah kehadiran bank-bank syariah yang semakin banyak dan serta dikeluarkannya fatwa bunga bank haram oleh MUI pada tahun 2003 yang diikuti oleh Organisasi Muhammadiyah pada tahun 2006.

Dalam beberapa kajian telah diteliti sejumlah faktor dan penyebab mengapa fatwa bunga bank haram yang dikeluarkan MUI tidak serta merta diikuti oleh sikap yang sama oleh seluruh umat Islam di Indonesia, dan hal yang sama juga tidak diikuti oleh pengajar- 
pengajar PAI di Perguruan Tinggi Umum. Penelitian ini menemukan akan ketidaksamaan pandangan sejumlah Dosen PAI di PTU terhadap fatwa MUI tersebut.

Jika menggunakan paradigma dikotomis yang dikemukakan Warde sebelumnya, maka dapat pula disimpulkan bahwa terdapat dua kelompok pandangan yang bersebrangan dalam menyikapi sistem keuangan syariah. Satu kelompok bisa dianggap kepada golongan modern,' cenderung pada pemahaman kontekstual yang berlandaskan semangat keagamaan dan menerima inovasi-inovasi non-Islam melalui pemahaman berbasis moral universal. $^{12}$

Keberadaan bunga bank adalah representasi dari 'modern dan kreasi 'non-Islam. Di sini kita harus menegaskan pembedaan bahwa sikap akademisi Islam yang menerima sistem bunga sebagai cara penghitungan harga produk keuangan, mereka hanya menerima bunga sebagai tehnik menghitung tanpa mengaitkan pada bagaimana cara pandang fikih formal terhadap setiap tambahan, artinya bunga yang diperkenankan bagi kelompok ini hanyalah bunga yang tidak memenuhi unsur-unsur ekploitatif, dan tidak menzalimi pihak lain sebagaimana dampak yang akan terjadi jika melegalkan transaksi riba di tengah masyarakat. Akan tetapi, tetap saja argumentasi ini tidak dapat diterima oleh kelompok yang bersebrangan karena sistem bunga bagi mereka selalu akan menjurus pada prilaku eksploitatif ( al zulm), sedikit maupun banyak, karenanya hukumnya tetap diharamkan.

Dalam penelitian ini, responden yang bersebrangan dengan kelompok modern adalah golongan tradisionalisme', jumlahnya lebih sedikit dibandingkan kelompok modern yakni $36 \%$ dari total responden. Kelompok yang berseberangan dengan modern, digambarkan sebagai pendekatan yang cenderung mengikuti teks-teks agama secara literal/tekstual. Akan tetapi pandangan haram bunga bank bagi sebagian dosen PAI tidak serta merta menjadikan mereka sama sekali tidak berinteraksi dengan bank konvensional. Penjelasan selanjutnya akan dipaparkan kemudian.

Di antara kelompok modern, terdapat satu kelompok yang berada di antaranya, yakni pandangan yang menyatakan bunga bank hukumnya syubhat. Ada beberapa tipe dalam kelompok ini, yakni mengharamkan sebagian dan membolehkan secara 'darurat' beberapa bentuk transaksi yang menggunakan sistem bunga, seperti membolehkan pada sektor pinjaman komersil dan melarangnya pada pinjaman konsumtif. Termasuk syubhat

${ }^{12}$ Ibrahim Warde, Islamic Finance in The Global Economy . (Edinburgh: Edinburgh University Press, (2000), h. . Buchori, M. N. (2012, November). Kajian Fiqh, antara Pendekatan Substansial dan Pendekatan Formal . Diambil kembali dari http://mazinov.wordpress.com/2012/11/01/antara-pendekatan-substansialdan-pendekatan-formal-dalam-kajian-fiqh/. 
jika pinjaman dikeluarkan oleh bank-bank yang menginvestasikan dananya pada sektorsektor yang tidak jelas kehalalannya.

Persoalan kontinuitas interaksi dengan bank konvensional bagi beberapa umat muslim agaknya tidak semata-mata masalah pandangan mereka tentang bunga bank saja, akan tetapi juga berkaitan dengan fungsi keberadaan bank konvensional bagi mereka. Keterikatan umat Islam terhadap bank konvensional juga ditunjukkan dari kepemilikan rekening bank konvensional. Dalam penelitian ini, seluruh responden (25 orang) mempunyai rekening bank konvensional, meskipun mereka mempunyai sikap dan pandangan yang berbeda-beda terhadap bunga bank, sebagaimana yang terungkap sebelumnya. Dalam dua diaqram berikut menggambarkan kondisi ini.

Tabel I. Kepemilikan Rekening Bank Konvensional

\begin{tabular}{|l|l|}
\hline $\begin{array}{l}\text { Kepemilikan rekening bank } \\
\text { konvensional }\end{array}$ & Jumlah \\
\hline Punya & 25 \\
\hline tidak punya & 0 \\
\hline
\end{tabular}

Keseluruhan responden memiliki rekening di bank konvensional, meskipun sikap dan pandangan mereka berbeda-beda tentang hukum bunga bank, bahkan sebagian mereka yang mengharamkannya atau pun memandangnya sebagai syubhat, namun sebagai seorang profesional yang menerima gaji dari suatu instansi, mayoritas dari mereka menerima gaji melalui transfer bank konvensional, oleh karenanya, meskipun mereka berpandangan bahwa bunga bank haram atau pun syubhat, mereka tetap diharuskan mempunyai rekening bank konvensional dengan fungsi payroll gaji. Sebagian lagi tidak hanya menggunakan bank konvensional sebagai media payroll gaji, namun juga berfungsi sebagai sarana menabung dan investasi. Hal ini menunjukkan bahwa pandangan sebagian responden (40\%) bahwa bunga bank halal, diikuti pula oleh interaksi mereka dengan konvensional yang tidak hanya memfungsikan sebagai media payroll gaji, namun berfungsi pula sebagai sarana investasi dan menyimpan uang. Diagram berikut menggambarkan fungsi rekening bank konvensional bagi responden penelitian. 
Diagram II. Fungsi Rekening Bank Konvesional bagi Responden

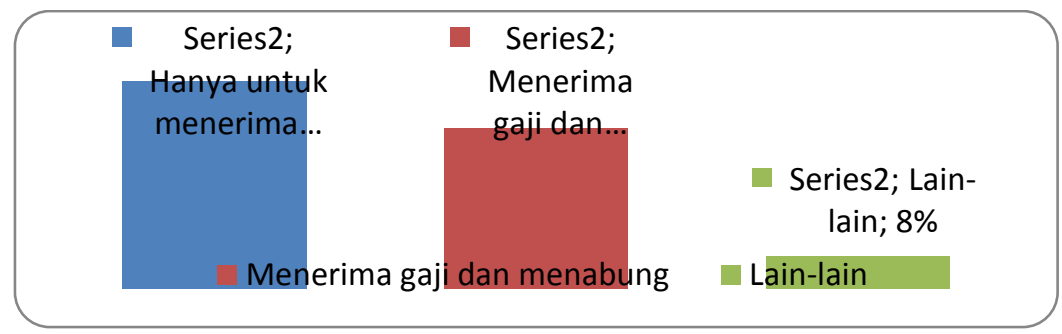

Selain berfungsi sebagai sarana payroll dan investasi, responden juga memanfaatkan bank konvensional untuk mengajukan kredit dan pinjaman untuk memenuhi kebutuhan mereka, seperti kredit kepemilikan rumah, kendaraan, dan barang-barang lainnya. Diagram di bawah ini menjelaskan bagaimana interaksi responden terhadap bank konvensional selain berfungsi sebagai payroll dan sarana invetasi.

\section{Diagram III. Kepemilikan Kredit (Pinjaman) di Bank Konvensional}

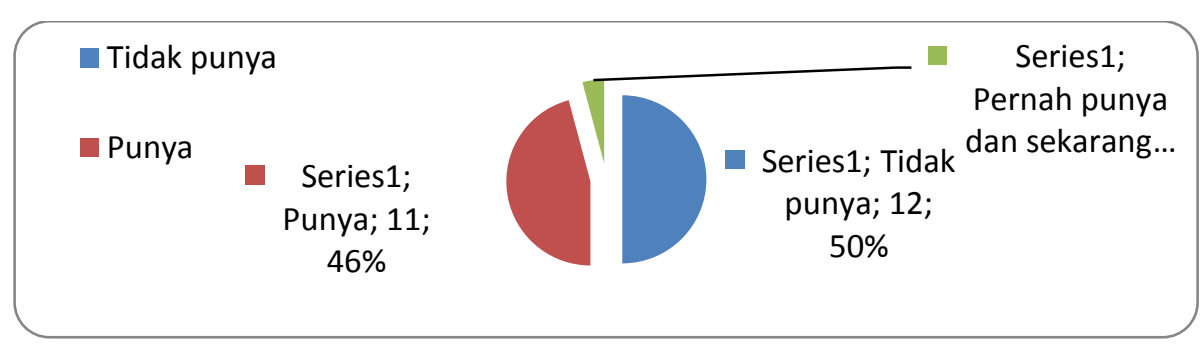

Berdasarkan diagram dapat diamati, beberapa responden (50\%) mengungkapkan bahwa mereka memanfaatkan bank konvensional untuk memenuhi kebutuhan finansial seperti kredit atau pinjaman. Artinya sikap sebagian responden yang memandang hukum bunga bank haram atau pun syubhat juga diikuti oleh interaksi yang cukup intens dengan bank konvensional. Kontinuitas interaksi mereka dianggap cukup lama karena transaksi kredit merupakan transaksi pinjaman yang relatif melewati durasi waktu yang cukup panjang.

\section{Pengetahun Dosen PAI di PTU tentang Perbankan Syariah}

Perbedaan pandangan dan sikap pada sebagian Dosen PAI di PTU tentang hukum bunga tampaknya telah menjadi sebuah pandangan yang cenderung mapan. Sebab setelah keberadaan bank syariah dan adanya fatwa haram yang dikeluarkan oleh MUI, tidak serta merta diikuti oleh pandangan yang sama. Bahkan kemapanan pandangan bahwa hukum bunga bank haram atau paling tidak hukumnya syubhat bukan disebabkan keawaman dan minimnya pengetahuan responden tentang sistem perbankan syariah. Hal ini dapat ditunjukkan dari diagram berikut. 
Diagram IV. Pengetahuan Responden tentang Bank Syariah

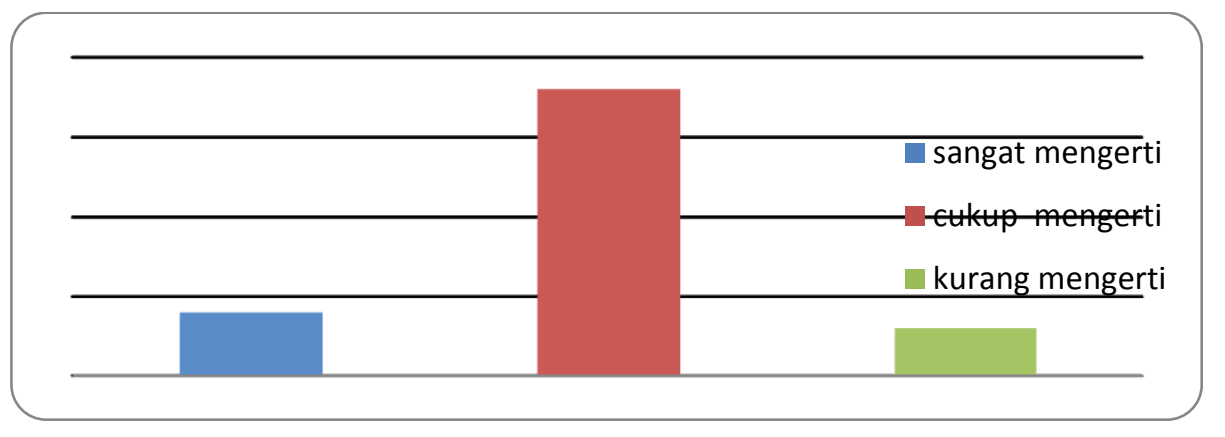

Awalnya, banyak yang menduga bahwa pengetahuan tentang bank syariah hanya dikuasai oleh dosen-dosen, akademisi, maupun praktisi ekonomi syariah, namun kenyataannya, responden yang merupakan Dosen PAI di PTU yang tidak mempunyai background keilmuan ekonomi syariah mengaku bahwa mereka mengerti dan mempunyai pengetahuan yang cukup tentang perbankan syariah. Hanya sedikit saja ( $12 \%$ responden) yang mengaku kurang mengerti tentang sistem perbankan syariah.

Penelitian ini memang tidak menelusuri secara mendalam pengetahuan mereka tentang bank syariah. Pertanyaan yang diajukan kepada responden memang bersifat umum, sehingga tidak dapat mengevaluasi sejauh mana pemahaman mereka tentang perbankan syariah. Karena bisa saja pengakuan meraka yang mengetahui secara baik tentang sistem perbankan syariah, namun kenyataannya sebaliknya tidak lah demikian. Asumsi ini dapat diperkuat dari pandangan sebagian besar responden yang menyatakan bahwa sistem perbankan syariah dan perbankan konvensional yang mempunyai sedikit perbedaan saja. Temuan ini dapat dilihat dalam diagram berikut ini:

\section{Diagram V. Perbandingan Bank Syariah dan Bank Konvensional}

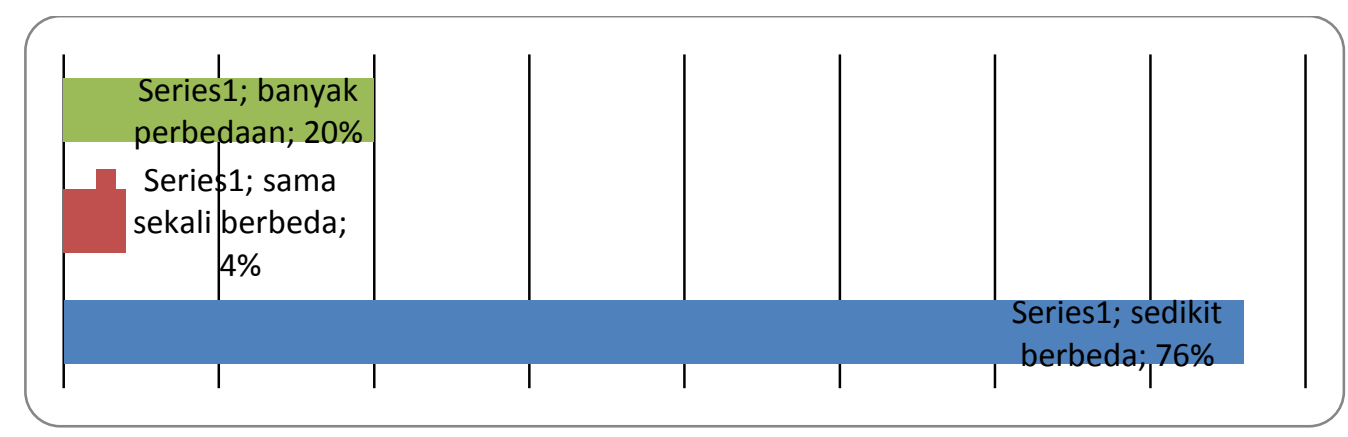

Berdasarkan angket yang disebarkan kepada responden didapatkan hasil bahwa 76\% atau mayoritas responden menilai bahwa sistem perbankan syariah hanya memiliki sedikit perbedaan atau hampir sama saja dengan perbankan konvensional, dan hanya $20 \%$ saja yang menganggap terdapat banyak perbedaan antara sistem perbankan syariah dan 
konvensional, dan hanya sedikit saja (4\%) yang menilai bank syariah sama sekali berbeda dengan bank konvensional. Temuan ini tentu akan menjadi sebuah catatan penting bagi ilmuan dan akademisi ekonomi syariah dan juga para praktisi syariah, karena temuan tersebut sedikit banyak menggambarkan ketidakberhasilan mereka dalam meyakinkan bahwa bank syariah dan konvensional mempunyai perbedaan yang siginfikan. Bahwa temuan ini juga menjadi pertimbangan penting dalam memahami mengapa terjadi perlambatan pertumbuhan perbankan syariah di Indonesia, dan salah satu faktornya adalah persepsi di beberapa kalangan dosen PAI di PTU yang menyamakan antara bank syariah dan bank konvensional. Pertanyaan yang cukup penting sebagai kajian di kalangan praktisi dan akademisi ekonomi syariah yakni sejauh mana peran dan kontribusi Dosen-dosen PAI di PTU seluruh wilayah Indonesia dalam ikut meningkatkan market share dan pertumbuhan bank syariah.

Dari beberapa temuan sebelumnya, pandangan dan sikap sebagian Dosen PAI tidak seiring sejalan dengan proogram percepatan perkembangan bank syariah di Indoensia. Dengan mengaitkan antara pandangan sebagian besar Dosen PAI di PTU terhadap kontribusi perlambatan sosialisasi perbankan syariah dapat diamati sejauh mana pemberian materi ekonomi dan perbankan syariah di kelas-kelas mata kuliah PAI, dan pandangan apa yang mereka ungkapkan ketika membandingkan antara bank syariah dan bank konvensional. Namun sebelumnya akan diungkapkan terlebih dahulu bagaimana interaksi mereka terhadap bank syariah melalui kepemilikan rekening bank syariah.

\section{Diagram VI. Kepemilikan Rekening Bank Syariah}

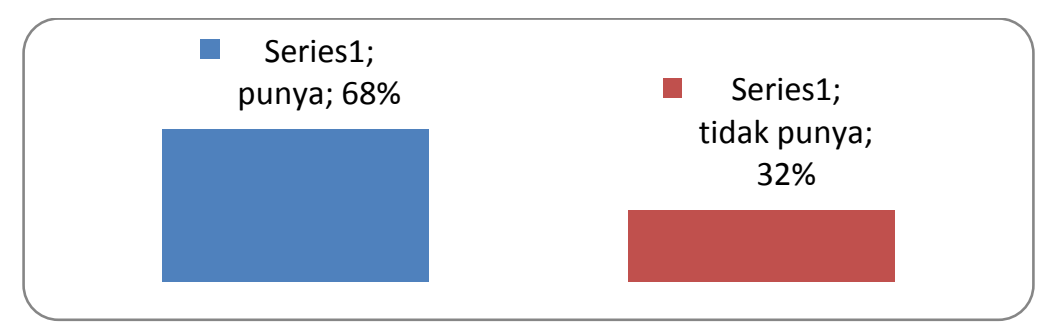

Berbeda dengan kepemilikan rekening bank konvensional, ternyata tidak semua responden mempunyai rekening bank syariah. Penelitian ini tidak bisa mengungkapkan secara mendalam apakan ketidakpunyaan rekening tersebut ada keterkaitannya dengan sikap dan pandangan mereka tentang bunga bank halal atau syubhat sehingga tidak tertarik untuk membuka rekening bank syariah. Mungkin terdapat sejumlah alasan lainnya yang tidak menjadi fokus penelitian ini, namun sedikit banyaknya dapat diasumsikan bahwa ketidakpunyaan rekening bank syariah dilatarbelakangi oleh pandangan mereka bahwa 
antara bank konvensional dan bank syariah hampir sama saja, bahkan hukum bunganya adalah halal.

\section{Kesimpulan}

Berdasarkan rumusan masalah dan hasil jawaban angket dari responden, maka dapat disimpulkan beberapa hal berikut:

1. Dosen PAI di PTU mempunyai pandangan dan sikap yang berbeda-beda tentang praktek perbankan konvensional. Dengan menggunakan teori yang dikemukakan Ibrahim Warde maka secara umum dapat disimpulkan bahwa terdapat tiga pandangan Dosen PAI di PTU terkait hal tersebut yakni, :

a. Sebagian besar responden (40\%) dapat dikelompokkan kepada golongan modern, yakni cenderung menerima konsep bunga sebagai instrumen transaksi di perbankan, dan menganggapnya sebagai transaksi yang halal, hal ini juga ditandai dengan kepemilikan rekening dan pinjaman di bank-bank konvensional.

b. Kelompok kedua berseberangan dengan pandangan kelompok pertama. Jika menggunakan teori Warde, mereka dapat digolongkan kepada kelompok tradisionalis, menganggap bunga bank adalah tambahan pinjaman, termasuk riba dan hukumnya haram. Namun kelompok ini tidak serta merta sama sekali tidak berinteraksi dengan bank konvensional, dikarenakan beberapa kondisi mereka masih tidak bisa menghindari pemanfaatan fungsi bank konvensional dalam kebutuhan finansial mereka, seperti berfungsi sebagai payroll gaji dari instansi tempat bekerja, oleh karenanya apapun pandangan Dosen PAI tentang hukum bunga bank konvensional, mereka tetap mempunyai rekening bank konvenisonal.

c. Terakhir adalah kelompok yang berada di antara tradisionalis dan modern. Jika dalam teori Warde hanya menyebutkan dua kelompok saja secara dikotomis, maka kelompok yang ketiga ini cenderung ada dalam dua kelompok tersebut. Dalam satu kondisi mereka menerima konsep kelompok modernis, akan tetapi di kondisi yang lain mereka cenderung tradisionalis. Kelompok ketiga ini dilihat dari pandangan mereka yang menyatakan bahwa hukum bunga bank adalah syubhat atau mereka hanya membolehkan pada bentuk-bentuk pinjaman tertentu seperti pinjaman komersil atau pinjaman yang dikeluarkan oleh Bank Negara.

Dosen PAI juga mempunyai pandangan yang berbeda mengenai perbankan syariah. Mayoritas responden beranggapan dan menilai perbankan syariah tidak 
jauh berbeda dengan perbankan konvensional, hanya beberapa responden yang sebelumnya menyikapi hukum bunga bank haram menyatakan bahwa terdapat banyak perbedaan antara bank konvensional dan bank syariah.

\section{E. Daftar Pustaka}

Abdurrahman Ghazaly, dkk, Fiqh Muamalat, (Jakarta, Kencana Prenada Media Group, 2010).

Buchori, M. N. (2012, November), Kajian Fiqh, antara Pendekatan Substansial dan Pendekatan Formal. http://mazinov.wordpress.com/2012/11/01/antara-pendekatansubstansial- dan-pendekatan-formal-dalam-kajian-fiqh/.

http://tarjih.muhammadiyah.or.id/muhfile/tarjih/download/Fatwa\%20082006_Bunga\%20Bank.pdf

https://ekbis.sindonews.com/read/1178444/178/industri-keuangan-syariah-jalan-di-tempat1486632486

https://www.hisbah.net/fatwa-mui-tentang-bunga-bank/

Husni Thoyar, “ Bunga Bank dan Riba dalam Perspektif Islam,” Jurnal Equibrilium, Ekonomi dan Kemasyarakatan, Vol 2, No 2 Mei-Agustus 2004.

Izzatul Mardhiah, Prinsip Keadilan Dalam Penetapan Biaya Ijarah di Pegadaian Syariah, (Semarang, Pangudi Ilmu, 2013).

Junaidi, "Persepsi Masyarakat untuk Memilih dan Tidak Memilih Bank Syariah (Studi Kota Palopo)," Jurnal Fokus Bisnis, Volume 14, No 02, bulan Desember 2015. http://download.portalgaruda.org/article.php? article $=450789 \& v a l=6380 \&$ title $=$ Perse psi\%20masyarakat\%20\%20untuk\%20memilih\%20dan\%20tidak\%20memilih\%20ban $\mathrm{k} \% 20$ syariah\%20(Studi\%20kota\%20palopo)

Sri-Edi Swasono," Ekonomi Islam dalam Pancasila, Paper International Seminar on Implemetation of Islamic Economics, Surabaya, 1-3 Agustus 2008.

Buchori, M. N. (2012, November). Kajian Fiqh, antara Pendekatan Substansial dan Pendekatan Formal Diambil kembali dari http://mazinov.wordpress.com/2012/11/01/antara-pendekatan-substansial- danpendekatan-formal-dalam-kajian-fiqh/.

Linangkung, E. (2017, Februari 9). https://ekbis.sindonews.com/read/1178444/178 /industri-keuangan-syariah-jalan-di-tempat-1486632486. Dipetik 2017

Rahmawati, Istinbath Hukum teuku Muhammad Hasbi Asy-Syiddieqy. Yogyakarta: Deepublish, 2015.

Warde, I, Islamic Finance in The Global Economy . Edinburgh: Edinburgh University Press, 2000. 